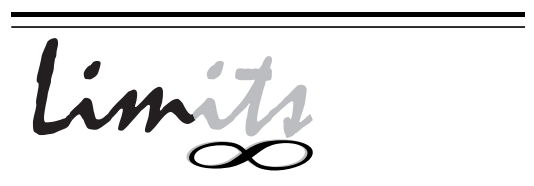

J. Math. and Its Appl.

ISSN : $1829-605 \mathrm{X}$

Vol. 4, No. 2, Nopember 2007, 9-15

\title{
MODEL SIKLUS BISNIS IS-LM DENGAN PERSAMAAN DIFERENSIAL TUNDAAN
}

\author{
IGN Rai Usadha ${ }^{1}$, Ni Ketut Tari T. ${ }^{2}$ \\ ${ }^{1}$ Jurusan Matematika, Institut Teknologi Sepuluh Nopember \\ ${ }^{2}$ UNUD Denpasar
}

\begin{abstract}
Abstrak
Sistem dinamik dapat diterapkan dalam berbagai bidang kehidupan, seperti pertumbuhan populasi, dan pertumbuhan ekonomi. Dalam bidang ekonomi, sistem dinamik diterapkan dalam bentuk model siklus bisnis. Ada beberapa model siklus bisnis, salah satu diantaranya model IS-LM. Dalam penelitian ini dianalisa model siklus bisnis IS-LM dengan parameter time delay. Perbedaan antara keputusan investasi dengan implementasinya menganjurkan untuk merumuskan model siklus bisnis IS-LM yang baru, yang memperlihatkan bahwa dinamika model sangat bergantung pada parameter time delay (waktu persiapan periode investasi). Dalam penelitian ini digunakan teorema bifurkasi Hopf untuk menunjukkan terjadinya limit cycle pada model IS-LM yang menggambarkan siklus dari model IS-LM. Katakunci: Bifurkasi Hopf, model IS-LM, siklus bisnis, time delay.
\end{abstract}

\section{Pendahuluan}

Sistem dinamik dapat dikembangkan dalam berbagai bidang kehidupan, seperti bidang teknik, biologi, ekonomi, dan ilmu-ilmu sosial lainnya. Umum- 
nya sistem dinamik dapat dimodelkan dalam bentuk persamaan diferensial, dan dianalisa kestabilan lokal dan global dari sistem tersebut.

Salah satu model yang merupakan sistem dinamik dalam bidang ekonomi, khususnya dalam ekonomi makro adalah model siklus bisnis. Model siklus bisnis ada beberapa macam, salah satunya adalah model siklus bisnis IS-LM yang melibatkan beberapa fungsi, seperti investasi $(I)$, saving (S), permintaan akan uang (L), dan persediaan uang (M). Model ini telah banyak dikembangkan, salah satunya oleh [2] yang menganalisa keberadaan orbit tertutup dengan menggunakan teorema bifurkasi Hopf [2].

Dari model tersebut, keputusan investasi hanya mempertimbangkan kejadian pada saat sekarang. Pada banyak aplikasi, diasumsikan suatu sistem yang menjadi perhatian, bahwa keadaan mendatang dari sistem tidak tergantung pada keadaan sebelumnya dan hanya ditentukan oleh keadaan saat ini. Apabila sistem tersebut dimodelkan dengan suatu persamaan yang menyatakan keadaan beserta percepatan perubahan keadaan tersebut, maka umumnya digunakan persamaan diferensial biasa atau persamaan diferensial parsial. Prinsip hubungan sebab akibat sering hanya merupakan suatu pendekatan awal untuk situasi sebenarnya, dan model yang lebih realistik harus meliputi keadaan sistem pada waktu sebelumnya [3].

Oleh karena itu dalam model siklus bisnis Kalecki, Kalecki mengasumsikan bahwa bagian yang disimpan dari keuntungan adalah investasi dan pertumbuhan modal bergantung pada keputusan investasi sebelumnya. Ini merupakan periode persiapan atau time delay [1]. Dalam penelitian ini, dengan menggunakan ide dari Kalecki maka perumusan model siklus bisnis diperumum seperti berikut [7]:

$$
\begin{aligned}
& \dot{Y}=\alpha\{I(Y, K, r)-S(Y, r)\} \\
& \dot{r}=\beta\{L(Y, r)-\bar{M}\} \\
& \dot{K}=I(Y(t-T), K, r)-\delta K
\end{aligned}
$$

dengan $T$ adalah parameter time delay.

Investasi bergantung pada pendapatan pada waktu keputusan investasi dibuat dan juga pada stok modal pada waktu investasi berakhir. Stok modal pada waktu investasi berakhir merupakan konsekuensi dari fakta 
bahwa pada waktu $t$ - $T$ terdapat beberapa investasi yang akan berakhir antara waktu $t-T$ dan $t$. Diasumsikan bahwa hasil stok modal dalam periode ini menjadi pertimbangan ketika investasi baru direncanakan. Dalam penelitian ini akan diaplikasikan teorema bifurkasi Hopf untuk memprediksi kejadian dari limit cycle untuk parameter time delay.

Dari uraian diatas, maka permasalahan yang dibahas dalam penelitian ini adalah:

1. Kestabilan linier model siklus bisnis IS-LM (??)

2. Perilaku penyelesaian model siklus bisnis IS-LM (??) dengan menggunakan teorema bifurkasi Hopf (menyelidiki keberadaan limit cycle).

\section{Model Siklus Bisnis IS-LM}

Model siklus bisnis IS-LM merupakan suatu sistem dinamik dalam bidang ekonomi yang melibatkan fungsi investasi $(I)$, fungsi saving $(S)$, permintaan akan uang $(L)$ dan persediaan uang $(M)$.

Investasi bergantung pada pendapatan pada waktu keputusan investasi dibuat dan juga pada stok modal pada waktu investasi berakhir. Stok modal pada waktu investasi berakhir merupakan konsekuensi dari fakta bahwa pada waktu $t$ - $T$ terdapat beberapa investasi yang akan berakhir antara waktu $t$ - $T$ dan $t$. Diasumsikan bahwa hasil stok modal dalam periode ini menjadi pertimbangan ketika investasi baru direncanakan.

Jika $I$ adalah investasi, $Y$ adalah gross product, $K$ adalah stok modal, $r$ adalah suku bunga (interest rate), $\alpha$ adalah index dalam pasar barang, $S$ adalah saving, $L$ adalah permintaan uang dan $\bar{M}$ adalah persediaan uang maka fungsi investasi bergantung pada $Y, K$, dan $r$, sedangkan fungsi saving dan permintaan uang bergantung pada $Y$ dan $r$. Sehingga laju pertumbuhan gross product dapat dinyatakan sebagai index dalam pasar barang $(\alpha)$ dikalikan dengan selisih dari investasi dan saving. Begitu juga dengan laju pertumbuhan suku bunga (interest rate) dapat dinyatakan sebagai index dalam pasar uang $(\beta)$ dikalikan dengan selisih antara permintaan uang dan persediaan uang. Sedangkan laju pertumbuhan stok modal dapat dinyatakan sebagai selisih dari investasi (yang didasarkan pada pendapatan pada 
waktu periode investasi sebelumnya) dan stok modal yang mengalami penurunan nilai sebesar $\delta$.

Sehingga model siklus bisnis IS-LM [7] dapat dinyatakan sebagai:

$$
\begin{aligned}
& \dot{Y}=\alpha\{I(Y, K, r)-S(Y, r)\} \\
& \dot{r}=\beta\{L(Y, r)-\bar{M}\} \\
& \dot{K}=I(Y(t-T), K, r)-\delta K
\end{aligned}
$$

\subsection{Penelitian Terkait}

[2] telah menggunakan teorema bifurkasi dalam membuktikan keberadaan limit cycle dalam model siklus bisnis IS-LM yang disebut juga sebagai Complete Keynesian System ([2]. Modelnya berbentuk:

$$
\begin{aligned}
& \dot{Y}=\alpha\{I(Y, r)-S(Y, r)\} \\
& \dot{r}=\beta\{L(Y, r)-\bar{M}\}
\end{aligned}
$$

Sedangkan [6] menggunakan teorema bifurkasi untuk memperlihatkan adanya limit cycle pada model siklus bisnis Kaldor-Kalecki. Dalam penelitian ini model direpresentasikan dalam bentuk sistem persamaan diferensial time delay, dimana modelnya didasarkan pada model Kaldor dan ide dari Kalecki tentang time delay (Krawiec and Szydowski, 2001). Modelnya berbentuk:

$$
\begin{aligned}
& \dot{Y}=\alpha\{I(Y, K)-S(Y, K)\} \\
& \dot{K}=I(Y(t-T), K)-\delta K
\end{aligned}
$$

[8] menyelidiki pengaruh delay pajak sebagai akibat dari kebijakan fiscal. Pemilihan delay sebagai parameter bifurkasi digunakan untuk mempelajari arah dan stabilitas solusi perodik dari bifurkasi. Dalam penelitian ini diperlihatkan kapan sistem tersebut stabil berdasarkan parameter delay pajak diatas [8].

\subsection{Model IS-LM}

Diasumsikan bahwa fungsi Investasi $I$, fungsi Saving $S$, dan permintaan akan uang $L$ bergantung secara linear pada argumen-argumennya. Suku 
bunga $r$ mempunyai hubungan yang berbanding terbalik dengan investasi sehingga semakin tinggi tingkat suku bunga maka investasi semakin turun. Stok modal mengalami penyusutan nilai sebesar $\delta$, sehingga fungsi investasi $(I)$ dapat dinyatakan sebagai besarnya pendapatan (dalam hal ini gross product) dikurangi modal dan suku bunga. Saving atau simpanan merupakan besarnya pendapatan ditambah suku bunga. Sedangkan pemintaan uang di pasar berbanding terbalik dengan suku bunga, semakin tinggi tingkat suku bunga semakin turun permintaan akan uang di pasar, sehingga fungsi permintaan akan uang $(L)$ dapat dinyatakan sebagai besarnya pendapatan (gross product) dikurangi besarnya suku bunga. Secara singkat dapat dinyatakan sebagai berikut:

$$
\begin{aligned}
& I=\eta Y-\delta_{1} K-\beta_{1} r \\
& S=l_{1} Y+\beta_{2} r \\
& L=l_{2} Y-\beta_{3} r
\end{aligned}
$$

dengan $\eta, \delta_{1}, l_{1}, l_{2}, \beta_{1}, \beta_{2}, \beta_{3}$ adalah konstanta-konstanta positif dalam interval $[0,1]$.

\subsection{Persamaan Karakteristik Model IS-LM}

Berdasarkan persamaan (5) maka sistem (2) dapat dibentuk menjadi

$$
\begin{aligned}
& \dot{Y}=\alpha\left\{\left\{\eta-l_{1}\right\} Y-\left\{\beta_{1}+\beta_{2}\right\} r-\delta_{1} K\right\} \\
& \stackrel{\bullet}{r}=\beta\left\{l_{2} Y-\beta_{3} r-\bar{M}\right\} \\
& \stackrel{\bullet}{K}=\eta Y(t-T)-\beta_{1} r-\left\{\delta+\delta_{1}\right\} K
\end{aligned}
$$

Sistem (6) memuat persamaan diferensial tundaan, sehingga untuk memperoleh titik setimbangnya maka dipertimbangkan kasus tanpa tundaan $(T=0)$, dan karena sistem (6) merupakan sistem yang autonomous (secara eksplisit tidak bergantung pada t) maka elemen $\eta Y(t-T)$ dengan $T=0$ dapat dituliskan sebagai $\eta Y$. Oleh karena itu dengan membentuk $\dot{Y}=0, \dot{r}=0, \dot{K}=0$, serta $T=0$ didapatkan titik setimbang $S=(\bar{Y}, \bar{r}, \bar{K})$, dengan 


$$
\begin{aligned}
& \bar{Y}=-\frac{\left(\delta \beta_{2}+\delta_{1} \beta_{2}+\delta \beta_{1}\right) \bar{M}}{-\beta_{3} l_{1} \delta_{1}-\beta_{3} l_{1} \delta-\beta_{1} l_{2} \delta+\beta_{3} \eta \delta-\beta_{2} l_{2} \delta_{1}-\beta_{2} l_{2} \delta} \\
& \bar{r}=-\frac{\left(-l_{1} \delta_{1}-l_{1} \delta+\eta \delta\right) \bar{M}}{-\beta_{3} l_{1} \delta_{1}-\beta_{3} l_{1} \delta-\beta_{1} l_{2} \delta+\beta_{3} \eta \delta-\beta_{2} l_{2} \delta_{1}-\beta_{2} l_{2} \delta} \\
& \bar{K}=-\frac{\left(l_{1} \beta_{1}+\eta \beta_{2}\right) \bar{M}}{-\beta_{3} l_{1} \delta_{1}-\beta_{3} l_{1} \delta-\beta_{1} l_{2} \delta+\beta_{3} \eta \delta-\beta_{2} l_{2} \delta_{1}-\beta_{2} l_{2} \delta}
\end{aligned}
$$

Selanjutnya akan dicari persamaan karakteristik dari sistem (6). Persamaan karakteristik dibentuk melalui:

$$
|A-\lambda I|=0
$$

dengan $A$ adalah matriks koefisien dari sistem (6). Persamaan ketiga dari sistem persamaan (6) memuat parameter delay (tundaan) sehingga substitusinya berbeda dengan persamaan diferensial yang tidak memuat tundaan (persamaan diferensial biasa). Dalam persamaan diferensial biasa, substitusi yang digunakan adalah $y(t)=e^{\lambda t}$. Sehingga untuk $Y(t-T)$, substitusinya adalah

$$
\begin{aligned}
Y(t-T) & =e^{\lambda(t-T)} \\
& =e^{\lambda t} \cdot e^{-\lambda T} \\
& =e^{-\lambda T} Y(t)
\end{aligned}
$$

dengan $e^{-\lambda T}=$ konstanta

Selanjutnya sistem (6) dapat ditulis sebagai

$$
\begin{aligned}
& \dot{Y}=\alpha\left\{\left\{\eta-l_{1}\right\} Y-\left\{\beta_{1}+\beta_{2}\right\} r-\delta_{1} K\right\} \\
& \dot{r}=\beta\left\{l_{2} Y-\beta_{3} r-\bar{M}\right\} \\
& \dot{K}=\eta e^{-\lambda T} Y-\beta_{1} r-\left\{\delta+\delta_{1}\right\} K
\end{aligned}
$$

Oleh karena itu $|A-\lambda I|=0$ menjadi

$$
\begin{array}{ccc}
\alpha\left\{\eta-l_{1}\right\}-\lambda & -\alpha\left\{\beta_{1}+\beta_{2}\right\} & -\alpha \delta_{1} \\
\beta l_{2} & -\beta \beta_{3}-\lambda & 0 \\
\eta e^{-\lambda T} & -\beta_{1} & -\left\{\delta+\delta_{1}\right\}-\lambda
\end{array} \mid=0
$$


sehingga persamaan karakteristik dari persamaan (6) berbentuk:

$$
\lambda^{3}+A \lambda^{2}+B \lambda+C+D \lambda e^{-\lambda T}+E e^{-\lambda T}=0
$$

dengan

$$
\begin{aligned}
& A=\delta+\delta_{1}+\beta \beta_{3}-\alpha\left(\eta-l_{1}\right), \\
& B=\left(\delta+\delta_{1}\right)\left(\beta \beta_{3}-\alpha\left(\eta-l_{1}\right)\right)+\alpha \beta l_{2}\left(\beta_{1}+\beta_{2}\right)-\alpha \beta \beta_{3}\left(\eta-l_{1}\right), \\
& C=-\alpha \beta \beta_{1} l_{2} \delta_{1}-\left(\delta+\delta_{1}\right) \alpha \beta\left(\beta_{3}\left(\eta-l_{1}\right)-l_{2}\left(\beta_{1}+\beta_{2}\right)\right), \\
& D=\alpha \eta \delta_{1} \\
& E=\alpha \beta \beta_{3} \eta \delta_{1} .
\end{aligned}
$$

Persamaan transendental (7) memuat $e^{-\lambda T}$ sehingga tidak dapat diselesaikan secara eksak. Untuk itu perlu dilakukan pendekatan lain yaitu dengan pendekatan linear dan pendekatan dalam ruang kompleks.

\subsection{Pendekatan Linear}

Untuk time delay $T$ yang kecil, pendekatan linear sangat cocok untuk memperoleh titik bifurkasi.

Untuk $T$ yang sangat kecil maka $e^{-\lambda T} \approx 1-\lambda T$, sehingga persamaan (7) menjadi

$$
\begin{aligned}
& \lambda^{3}+A \lambda^{2}+B \lambda+C+D \lambda(1-\lambda T)+E(1-\lambda T)=0 \\
& \lambda^{3}+A \lambda^{2}+B \lambda+C+D \lambda-D \lambda^{2} T+E-\lambda T E=0 \\
& \lambda^{3}+(A-D T) \lambda^{2}+(B+D-E T) \lambda+C+E=0
\end{aligned}
$$

Dengan teorema bifurkasi Hopf dan kriteria Routh-Hurwitz, maka terjadi bifurkasi Hopf pada nilai $T=T_{0}$ dengan

$$
A-D T_{0}>0, B+D-E T_{0}>0, C+E>0
$$

dan

$$
\left(A-D T_{0}\right)\left(B+D-E T_{0}\right)=C+E
$$

Misalkan $g(\lambda, T)=\lambda^{3}+(A-D T) \lambda^{2}+(B+D-E T) \lambda+C+E=0$ maka dapat ditentukan g pada $T=T_{0}, g\left(\lambda, T_{0}\right)=\lambda^{3}+s \lambda^{2}+k^{2} \lambda+k^{2} s$ dengan $s=\left(A-D T_{0}\right), k^{2}=\left(B+D-E T_{0}\right)$. 
Nilai eigen dari persamaan (6) diperoleh dengan memfaktorkan $g\left(\lambda, T_{0}\right)=0$ yaitu:

$$
\begin{aligned}
g\left(\lambda, T_{0}\right) & =0 \\
\lambda^{3}+s \lambda^{2}+k^{2} \lambda+k^{2} s & =0 \\
(\lambda+s)\left(\lambda^{2}+k^{2}\right) & =0
\end{aligned}
$$

sehingga didapatkan

$$
\begin{aligned}
& \lambda_{0}\left(T_{0}\right)=-s=-\left(A-D T_{0}\right), \\
& \lambda_{1,2}\left(T_{0}\right)= \pm i k= \pm i\left(B+D-E T_{0}\right)^{\frac{1}{2}}
\end{aligned}
$$

Selanjutnya, akan ditunjukkan bahwa syarat transversal terpenuhi, yaitu $\operatorname{Re}\left(\frac{d}{d T}\left(\lambda\left(T_{0}\right)\right)\right) \neq 0$

Diferensiasi total $g(\lambda(T), T)$ menghasilkan

$$
\begin{aligned}
& d g=0 \\
& \frac{\partial g}{\partial \lambda} d \lambda+\frac{\partial g}{\partial T} d T=0 \\
& \frac{d \lambda}{d T}=-\frac{\frac{\partial g}{\partial T}}{\frac{\partial g}{\partial \lambda}}=-\frac{-D \lambda^{2}-E \lambda}{3 \lambda^{2}+2(A-D T) \lambda+B+D-E T}
\end{aligned}
$$

Dihitung turunan g untuk $\lambda=\lambda_{1}$ pada saat $T_{0}$, diperoleh

$$
\begin{aligned}
\frac{d}{d T}\left(\lambda_{1}\left(T_{0}\right)\right)= & -\frac{-D(i k)^{2}-E(i k)}{3(i k)^{2}+2\left(A-D T_{0}\right) i k+B+D-E T_{0}} \\
= & -\frac{D k^{2}-i E k}{x+y} \\
= & \frac{D k^{2}-i E k}{x+y} \cdot \frac{x-y}{x-y} \\
= & \frac{\left(D k^{2}-i E k\right)\left(-3 k^{2}+B+D-E T_{0}-i 2 k\left(A-D T_{0}\right)\right)}{\left(-3 k^{2}+B+D-E T_{0}\right)^{2}+\left(2 k\left(A-D T_{0}\right)\right)^{2}}, \text { sehingga } \\
& \frac{d}{d T}\left(\lambda_{1}\left(T_{0}\right)\right)=-\frac{\left(D k^{2}-i E k\right)(x-y)}{P^{2}+R^{2}}
\end{aligned}
$$


dengan

$x=\left(-3 k^{2}+B+D-E T_{0}\right)$

$y=\left(i 2 k\left(A-D T_{0}\right)\right)$

$P=-3 k^{2}+B+D-E T_{0}$

$R=2 k\left(A-D T_{0}\right)$

Bagian real dari (11) adalah

$R e\left(\frac{d}{d T}\left(\lambda_{1}\left(T_{0}\right)\right)\right)=-\frac{D k^{2}\left(-3 k^{2}+B+D-E T_{0}\right)-2 E k^{2}\left(A-D T_{0}\right)}{P^{2}+R^{2}}$.

Ada dua kemungkinan yang terjadi, yaitu

1. $\operatorname{Re}\left(\frac{d}{d T}\left(\lambda_{1}\left(T_{0}\right)\right)\right)>0$

$-\frac{D k^{2}\left(-3 k^{2}+B+D-E T_{0}\right)-2 E k^{2}\left(A-D T_{0}\right)}{P^{2}+R^{2}}>0$,

karena $P^{2}+R^{2}$ pasti positif, maka haruslah

$$
\begin{array}{r}
D k^{2}\left(-3 k^{2}+B+D-E T_{0}\right)-2 E k^{2}\left(A-D T_{0}\right)<0 \\
D k^{2}\left(-3 k^{2}+B+D-E T_{0}\right)<2 E k^{2}\left(A-D T_{0}\right) \\
D k^{2}\left(-3 k^{2}+k^{2}\right)<2 E k^{2}\left(A-D T_{0}\right) \\
-D k^{2}<E\left(A-D T_{0}\right),
\end{array}
$$

sehingga, $R e\left(\frac{d}{d T}\left(\lambda_{1}\left(T_{0}\right)\right)\right)>0$ ekivalen dengan

$$
-D\left(B+D-E T_{0}\right)<E\left(A-D T_{0}\right)
$$

Perhatikan bahwa untuk D dan E positif, pertidaksamaan (10) terpenuhi jika kondisi $\left(A-D T_{0}\right)>0$ dan $\left(B+D-E T_{0}\right)>0$ terpenuhi.

2. $\operatorname{Re}\left(\frac{d}{d T}\left(\lambda_{1}\left(T_{0}\right)\right)\right)<0$

Dengan cara yang sama seperti kemungkinan pertama, diperoleh

$$
-\frac{D k^{2}\left(-3 k^{2}+B+D-E T_{0}\right)-2 E k^{2}\left(A-D T_{0}\right)}{P^{2}+R^{2}}<0
$$

karena $P^{2}+R^{2}$ pasti positif, maka haruslah

$$
\begin{array}{r}
D k^{2}\left(-3 k^{2}+B+D-E T_{0}\right)-2 E k^{2}\left(A-D T_{0}\right)>0 \\
D k^{2}\left(-3 k^{2}+B+D-E T_{0}\right)>2 E k^{2}\left(A-D T_{0}\right) \\
D k^{2}\left(-3 k^{2}+k^{2}\right)>2 E k^{2}\left(A-D T_{0}\right) \\
-D k^{2}>E\left(A-D T_{0}\right),
\end{array}
$$


sehingga, $R e\left(\frac{d}{d T}\left(\lambda_{1}\left(T_{0}\right)\right)\right)<0$ ekivalen dengan

$$
-D\left(B+D-E T_{0}\right)>E\left(A-D T_{0}\right)
$$

untuk D dan E positif, pertidaksamaan (13) terpenuhi jika kondisi $\left(A-D T_{0}\right)<0$ dan $\left(B+D-E T_{0}\right)<0$ terpenuhi.

Kondisi terakhir ini tidak sesuai dengan kriteria Routh-Hurwitz, sehingga yang memenuhi adalah kemungkinan pertama yaitu $\operatorname{Re}\left(\frac{d}{d T}\left(\lambda_{1}\left(T_{0}\right)\right)\right)>0$, dan dapat disimpulkan bahwa $\operatorname{Re}\left(\frac{d}{d T}\left(\lambda\left(T_{0}\right)\right)\right) \neq 0$. Menurut teorema bifurkasi Hopf, hal ini menjamin adanya limit cycle pada saat $T=T_{0}$ dengan $A-D T_{0}>0$, $B+D-E T_{0}>0, C+E>0$ dan $\left(A-D T_{0}\right)\left(B+D-E T_{0}\right)=C+E$ terpenuhi.

\section{Pendekatan Dalam Ruang Kompleks (Analisa Bifurkasi Hopf)}

Untuk time delay yang lebih panjang, pendekatan linear tidak efektif lagi digunakan, sehingga diperlukan pendekatan yang lain. Dengan mengambil $\lambda=\sigma+i \omega$, persamaan (7) dapat ditulis dalam bentuk bagian real dan bagian imajiner.

$(\sigma+i \omega)^{3}+A(\sigma+i \omega)^{2}+B(\sigma+i \omega)+C+D\left((\sigma+i \omega) e^{-(\sigma+i \omega) T}\right)+E e^{-(\sigma+i \omega) T}=0$

Sehingga bagian real persamaan (7) berbentuk

$\sigma^{3}-3 \sigma \omega+A \sigma^{2}-A \omega^{2}+B \sigma+C+e^{-\sigma T}(D \sigma \cos \omega T+D \omega \sin \omega T+E \cos \omega T)=0$,

sedangkan bagian imajinernya adalah

$3 \sigma^{2} \omega-\omega^{2}+2 A \sigma \omega+B \omega+e^{-\sigma T}(D \omega \cos \omega T-D \sigma \sin \omega T-E \sin \omega T)=0$.

Untuk mendapatkan titik bifurkasi yang pertama, diambil $\sigma=0$. Sehingga bagain real dan bagian imajiner diatas direduksi menjadi 


$$
\begin{aligned}
& -A \omega^{2}+C+D \omega \sin \omega T+E \cos \omega T=0 \\
& -\omega^{3}+B \omega+D \omega \cos \omega T-E \sin \omega T=0
\end{aligned}
$$

Jika titik bifurkasi pertama adalah $\left(\omega_{b i f}, T_{b i f}\right)$, maka titik bifurkasi yang lain $(\omega, T)$ harus memenuhi

$$
\omega T=\omega_{b i f} T_{b i f}+2 n \pi, n=1,2, \ldots
$$

Selanjutnya kedua persamaan (14) dan (15) dibentuk menjadi

$$
\begin{aligned}
& -A \omega^{2}+C=-D \omega \sin \omega T-E \cos \omega T \\
& -\omega^{3}+B \omega=-D \omega \cos \omega T+E \sin \omega T
\end{aligned}
$$

Persamaan (16) dan (17) dikuadratkan, akan menghasilkan

$$
\begin{aligned}
& A \omega^{4}-2 A C \omega^{2}+C^{2}=D^{2} \omega^{2} \sin ^{2} \omega T+2 D \omega E \sin \omega T \cos \omega T+E^{2} \cos ^{2} \omega T \\
& \omega^{6}-2 B \omega^{4}+B^{2} \omega^{2}=D^{2} \omega^{2} \cos ^{2} \omega T-2 D \omega E \sin \omega T \cos \omega T+E^{2} \sin ^{2} \omega T
\end{aligned}
$$

Dengan menjumlahkan persamaan (18) dan (19), maka diperoleh

$$
\begin{aligned}
& \omega^{6}+\left(A^{2}-2 B\right) \omega^{4}+\left(B^{2}-2 A C\right) \omega^{2}+C^{2}= \\
& D^{2} \omega^{2}\left(\sin ^{2} \omega T+\cos ^{2} \omega T\right)+E^{2}\left(\sin ^{2} \omega T+\cos ^{2} \omega T\right),
\end{aligned}
$$

karena sifat fungsi trigonometri yaitu $\sin ^{2} \omega T+\cos ^{2} \omega T=1$, maka

$$
\omega^{6}+\left(A^{2}-2 B\right) \omega^{4}+\left(B^{2}-2 A C\right) \omega^{2}+C^{2}=D^{2} \omega^{2}+E^{2},
$$

sehingga, didapatkan

$$
\omega^{6}+\left(A^{2}-2 B\right) \omega^{4}+\left(B^{2}-2 A C-D^{2}\right) \omega^{2}+C^{2}-E^{2}=0
$$

Persamaan (20) merupakan persamaan kubik dalam $\omega^{2}$ dan sisi kiri dari persamaan ini bernilai positif untuk nilai $\omega^{2}$ yang besar dan akan bernilai 
negatif untuk $\omega=0$ dan $C^{2}<E^{2}$. Oleh karena itu, jika kondisi diatas terpenuhi, maka persamaan (20) mempunyai paling sedikit satu akar real positif.

Berikut ini Lemma yang menunjukkan bahwa suatu persamaan kubik mempunyai paling sedikit satu akar real positif.

Lemma 3.1 [5]

Syarat perlu dan cukup bahwa persamaan kubik $z^{3}+a_{1} z^{2}+a_{2} z+a_{3}=0$ dengan $a_{3}>0$, mempunyai paling sedikit satu akar positif adalah:

1. berlaku salah satu dari

a. $a_{1}<0 a_{2} \geq 0$ dan, $a_{1}^{2}>3 a_{2}$ atau

b. $a_{2}<0$

2. $\Delta<0$, dengan $\Delta=\frac{4}{27} a_{2}^{3}-\frac{1}{27} a_{1}^{2} a_{2}^{2}+\frac{4}{27} a_{1}^{3} a_{3}-\frac{2}{3} a_{1} a_{2} a_{3}+a_{3}^{3}$

Untuk membuktikan terjadi bifurkasi Hopf pada $T=$ Tbif , maka perlu ditunjukkan bahwa $\operatorname{Re}\left(\left.\frac{d}{d T}(\lambda(T))\right|_{T=T_{b i f}}\right) \neq 0$. Misalkan $G(\lambda(T), T)=$ $\lambda^{3}+A \lambda^{2}+B \lambda+C+D \lambda e^{-\lambda T}+E e^{-\lambda T}$, maka diferensiasi $G(\lambda(T), T)$ menghasilkan

$$
\begin{aligned}
d G & =0 \\
\frac{\partial G}{\partial \lambda} d \lambda+\frac{\partial G}{\partial T} d T & =0 \\
\frac{d \lambda}{d T} & =-\frac{\frac{\partial G}{\partial T}}{\frac{\partial G}{\partial \lambda}} \\
& =-\frac{\left(-D \lambda^{2} e^{-\lambda T}-E \lambda e^{-\lambda T}\right)}{3 \lambda^{2}+2 A \lambda+B-T D \lambda e^{-\lambda T}+D e^{-\lambda T}-T E e^{-\lambda T}} \\
& =\frac{\left(D \lambda^{2}+E \lambda\right) e^{-\lambda T}}{3 \lambda^{2}+2 A \lambda+B+(D-D T \lambda-E T) e^{-\lambda T}}
\end{aligned}
$$

Untuk $\mathrm{T}=$ Tbif dan $\lambda=i \omega_{b i f}$

$\operatorname{Re}\left(\left.\frac{d}{d T}(\lambda(T))\right|_{\begin{array}{c}T=T_{b i f} \\ \lambda=i \omega_{b i f}\end{array}}\right)=\frac{3 \omega_{b i f}^{3}\left(\omega_{b i f}^{3}-B \omega_{b i f}\right)+B \omega_{b i f}\left(-\omega_{b i f}^{3}+B \omega_{b i f}\right)+2 A \omega_{b i f}^{2}\left(A \omega_{b i f}^{2}-C\right)-D^{2} \omega_{b i f}^{2}}{P_{1}^{2}+Q_{1}^{2}}$ 


$$
\begin{aligned}
& =\frac{3 \omega_{b i f}^{6}-4 B \omega_{b i f}^{4}+B^{2} \omega_{b i f}^{2}+2 A^{2} \omega_{b i f}^{4}-2 A C \omega_{b i f}^{2}-D^{2} \omega_{b i f}^{2}}{P_{1}^{2}+Q_{1}^{2}} \\
& =\frac{\omega_{b i f}^{2}\left(3 \omega_{b i f}^{4}+2 \omega_{b i f}^{2}\left(A^{2}-2 B\right)+B^{2}-2 A C-D^{2}\right)}{P_{1}^{2}+Q_{1}^{2}}
\end{aligned}
$$

dengan

$$
\begin{gathered}
P_{1}=-3 \omega_{b i f}^{2}+B+T_{b i f}\left(-A \omega_{b i f}^{2}+C\right)+D \cos \omega_{b i f} T_{b i f} \\
Q_{1}=2 A \omega_{b i f}+T_{b i f}\left(-\omega_{b i f}^{3}+B \omega_{b i f}\right)-D \sin \omega_{b i f} T_{b i f} .
\end{gathered}
$$

Misalkan $x=\omega_{b i f}^{2}$, maka persamaan (20) menjadi

$$
f(x)=x^{3}+\left(A^{2}-2 B\right) x^{2}+\left(B^{2}-2 A C-D^{2}\right) x+C^{2}-E^{2}
$$

dan

$$
f^{\prime}(x)=3 x^{2}+2\left(A^{2}-2 B\right) x+\left(B^{2}-2 A C-D^{2}\right)
$$

Jika $\omega_{b i f}$ adalah akar positif terkecil dari persamaan (20) (kecuali jika merupakan akar kembar maka dipilih akar terkecil berikutnya), maka

$$
\left.f^{\prime}(x)\right|_{T=T_{b i f}}>0 .
$$

Oleh karena itu,

$$
\left.\frac{d \sigma}{d T}\right|_{T=T_{b i f}}=\frac{\omega_{b i f}^{2} f^{\prime}\left(\omega_{b i f}^{2}\right)}{P_{1}^{2}+Q_{1}^{2}}>0,
$$

yang memperlihatkan bahwa syarat transversal terpenuhi, sehingga terbukti terjadi bifurkasi Hopf pada saat $T=T_{b i f}$.

Dari analisa bifurkasi Hopf diatas, jika Lemma 3.1 terpenuhi dan $\omega_{b i f}$ adalah akar positif terkecil dari persamaan (20) (kecuali jika merupakan akar kembar maka dipilih akar terkecil berikutnya), maka bifurkasi Hopf terjadi pada saat $T$ melewati $T_{b i f}$.

\section{Contoh 1}

Jika

$$
\begin{aligned}
& \alpha=3, \beta=2, \delta=0.1, \delta_{1}=0.5, \eta=0.3, l_{1}=0.2, l_{2}=0.1, \\
& \bar{M}=0.05, \beta_{1}=\beta_{2}=\beta_{3}=0.2,
\end{aligned}
$$


maka sistem (20) menjadi

$$
\begin{aligned}
& \stackrel{\bullet}{Y}=0.3 Y-1.2 r-1.5 K \\
& \dot{r}=0.2 Y-0.4 r-0.1 \\
& \stackrel{\bullet}{K}=0.3 Y(t-T)-0.2 r-0.6 K
\end{aligned}
$$

Persamaan karakteristik (20) akan berbentuk:

$$
\lambda^{3}+0.7 \lambda^{2}+0.18 \lambda+0.012+0.45 \lambda e^{-\lambda T}+0.18 e^{-\lambda T}=0
$$

Dengan menggunakan persamaan (14) dan (15) maka diperoleh $T_{b i f}=$ 0.740471. Karena Lemma 3.1 terpenuhi dan $\omega_{b i f}$ adalah akar positif terkecil dari persamaan (20), maka bifurkasi Hopf terjadi pada saat $T$ melewati $T_{b i f}=$ 0.740471 , dengan nilai eigen

$$
\begin{aligned}
& \lambda_{0}\left(T_{b i f}\right)=-0.382583 \\
& \lambda_{1,2}\left(T_{b i f}\right)= \pm 0.6993 \mathrm{i}
\end{aligned}
$$

Oleh karena itu periode dari limit cycle adalah

$$
\tilde{T}=\frac{2 \pi}{\left|\lambda\left(T_{b i f}\right)\right|}=\frac{2 \pi}{0.6993}=8.98496
$$

yang menggambarkan bahwa periode dari sistem ekonomi (dalam hal ini model IS-LM) adalah sekitar 9 satuan waktu.

Selanjutnya akan ditampilkan hasil plotting time series dari Contoh 1 yaitu Gambar 1, Gambar 2, dan Gambar 3.

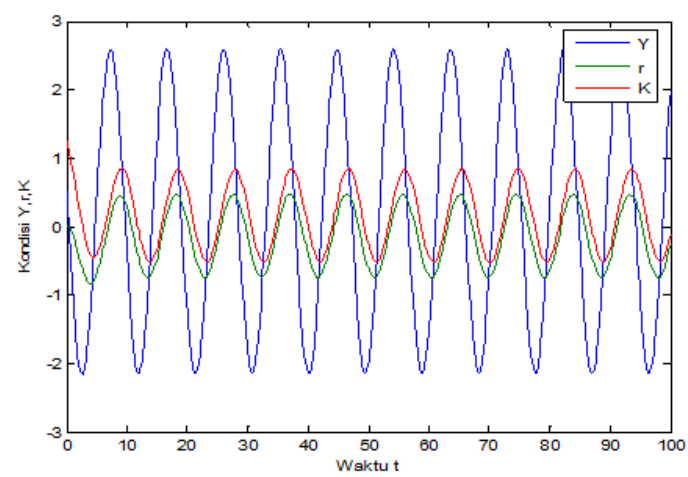

Gambar 1: Grafik Penyelesaian Model IS-LM pada $T_{b i f}=0.740471$ 


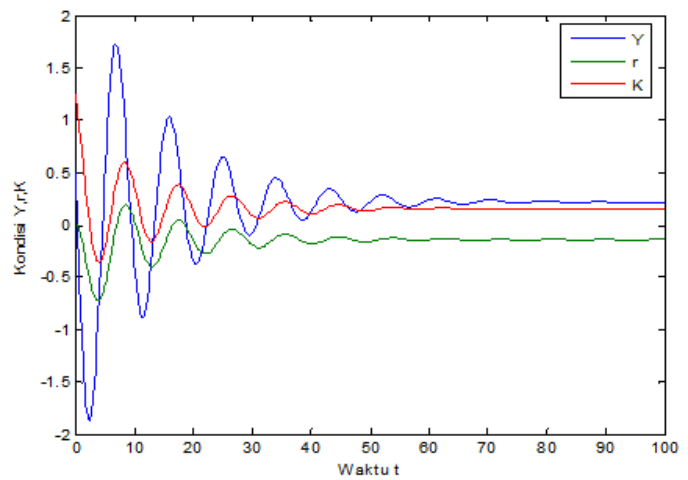

Gambar 2: Grafik Penyelesaian Model IS-LM pada $T=0.4$

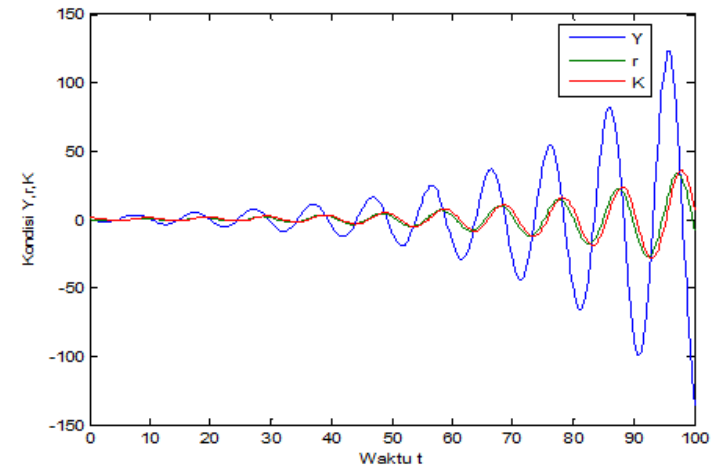

Gambar 3: Grafik Penyelesaian Model IS-LM pada $T=1$

Gambar 1 menunjukkan terjadi limit cycle pada $T_{b i f}=0.740471$, hal ini menggambarkan periode dari model IS-LM sekitar 9. Gambar 2 menunjukkan struktur orbit di dalam limit cycle akan menjauhi limit cycle ( terlihat bahwa osilasinya teredam), sedangkan Gambar 3 menunjukkan struktur orbit di luar limit cycle akan menjauhi limit cycle (osilasinya semakin membesar). Secara sederhana dapat digambarkan bahwa limit cyclenya tidak stabil (Gambar 4)).

Lingkaran biru menunjukkan limit cycle dari model IS-LM (Gambar 1), sedangkan orbit spiral di dalam limit cycle menunjukkan Gambar 2 dan orbit spiral di luar limit cycle menunjukkan Gambar 3. Sehingga dapat dikatakan bahwa bifurkasi Hopf yang terjadi dalam Contoh 1 merupakan bifurkasi Hopf Subkritikal (tidak stabil). 


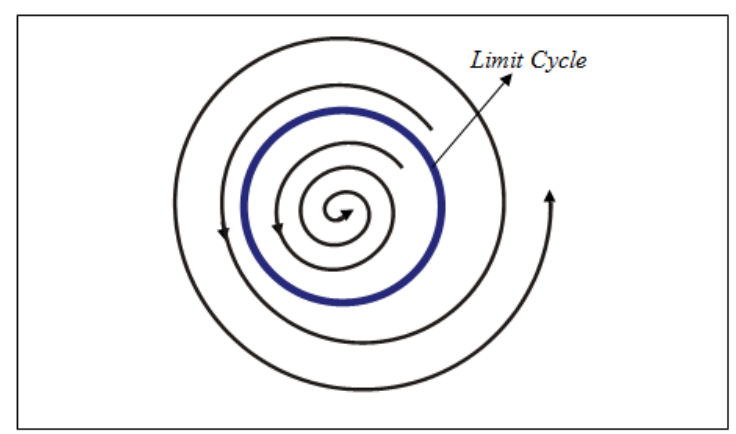

Gambar 4: Ilustrasi sederhana dari limit cycle yang tidak stabil

\section{Kesimpulan}

Kesimpulan yang diperoleh dari analisa dan aplikasi bifurkasi Hopf pada model siklus bisnis IS-LM adalah

1. Dari model diperoleh persamaan karakteristik yang tidak dapat diselesaikan secara eksak, sehingga perlu pendekatan lain yaitu pendekatan linear dan pendekatan dalam ruang kompleks (analisa bifurkasi Hopf).

2. Dengan pendekatan linear diperoleh persamaan karakteristik $\lambda^{3}+A \lambda^{2}+$ $B \lambda+C+D \lambda e^{-\lambda T}+E e^{-\lambda T}=0$ dan tiga nilai eigen dengan sepasang nilai eigen kompleks yang bagian realnya nol. Bifurkasi Hopf terjadi jika $A-D T_{0}>0, B+D-E T_{0}>0, C+E>0$ dan $\left(A-D T_{0}\right)\left(B+D-E T_{0}\right)=$ $C+E$ terpenuhi. Hal ini menjamin adanya limit cycle pada nilai $T=T_{0}$.

3. Pada pendekatan dalam ruang kompleks (analisa bifurkasi Hopf), bifurkasi Hopf terjadi pada saat $T$ melewati $T_{b i f}$.

\section{Pustaka}

[1] Kalecki, M., A Macrodynamic Theory of Business Cycle, Econometrica.3, (327-344), 1935

[2] Torre, V., Existence of Limit Cycle and Control in Complete Keynesian System by Theory of Bifurcation, Econometrica.45 (1457-1466), 1977.

[3] Hale, J.K. and Lunel, S.M.V., Introduction to Functional Differential Equations, Springer-Verlag New York, Inc., 1993. 
[4] Golubitsky, M. and Dellnitz, M., Linear Algebra and Differential Equations Using Matlab, Brooks/Cole Publishing Company, California, 1998.

[5] Khan, Q.J.A., Hopf Bifurcation in Multiparty Political Systems with Time Delay in Switching, Applied Mathematics Letter.13 (43-52), 2000.

[6] Kraweic, A. and Szydlowski, M., The Kaldor-Kalecki Model of Business Cycle as A Two-dimensional Dynamical System, Journal of Nonlinear Mathematical Physics.8 (266-271), 2001.

[7] Cai, J., Hopf Bifurcation in The IS-LM Business Cycle Model with Time Delay, Electronic Journal of Differential Equations.15 (1-6), 2005.

[8] Neamtu, M., Opris, D., Chilarescu, C., Hopf Bifurcation in A Dynamic IS-LM Model with Time Delay, asXiv:math.DS/0511322.1 (1-13), 2005. 